\title{
Assessment of technological gap and performance of integrated diseases management approach for wilt in cumin
}

\author{
Laxman Prasad Balai ${ }^{1 *}$, Dheeraj Singh ${ }^{2}$ and M.L. Meena ${ }^{2}$ \\ ${ }^{1}$ Krishi Vigyan Kendra, Dholpur (Rajasthan) India \\ ${ }^{2}$ ICAR- CAZRI, Krishi Vigyan Kendra, Pali (Rajasthan) India
}

\section{ARITCLE INFO}

Received : 06.02 .2020

Revised : 07.03.2020

Accepted : 20.03.2020

\section{KEY WORDS :}

Antagonistic, wilt disease, Fusarium oxysporum, technological interventions, Trichoderma harzianum

*Corresponding author:

Email : laxmanbhu08@gmail.com

\begin{abstract}
The experiment was carried out to assessment of technological gap and performance of integrated diseases management (IDM) approach as a resistant variety, chemical seed dressing, soil and seed treatment as a bio-agents for antagonistic fungi on growth of cumin Fusarium oxysporum f. sp. cumini pathogens under field conditions. This experiment was conducted on farmer trials (OFT) villages like Bhusi, Patelo Ki Dhani and Baldo Ki Dhani in Pali distract four year (2014 to 2017). This area is major growing cumin cultivation and here major problem face farmer every year cumin wilt disease due to reduction of yields. During this experiment disease incidence of wilt was observed to be lowest (Disease Incidences 5.00\%) when resistant variety GC-4, seed dressing Carbendazim @ 2.0g/ kg with Trichoderma harzianum @ 6g/ kg seed + application of $100 \mathrm{~kg}$ FYM enriched with T. harzianum @ 3.0 kg/ha for soil treatment before 15 days of sowing cumin. Maximum disease incidence $(24.00 \%)$ was observed when traditional farmers practice (no seed treatment). The adoption of recommended improved crop production technology and plant protection measures was poor. The OFT was effective in changing attitude, skill and knowledge of IDM approach and yield increased upto 28.64 per cent more over the traditional farmers practices. Results indicates that IDM approach increased net income by Rs. 20,593/-ha over farmers practices.
\end{abstract}

How to view point the article : Balai, Laxman Prasad, Singh, Dheeraj and Meena, M.L. (2020). Assessment of technological gap and performance of integrated diseases management approach for wilt in cumin. Internat. J. Plant Protec., 13(1) : 76-80, DOI : 10.15740/HAS/IJPP/13.1/7680, Copyright@ 2020: Hind Agri-Horticultural Society. 